\title{
Pengaruh Kinerja Keuangan, Rasio Pertumbuhan Perusahaan terhadap Nilai Perusahaan dan Free Cash Flow sebagai Variabel Moderating pada Perusahaan Freeport Indonesia, Tbk
}

\author{
Yesa Cahayaning Ramadhani \\ Program Studi Manajemen, Fakultas Ekonomi, Sekolah Tinggi Ilmu Ekonomi Indonesia \\ (STIESIA) Surabaya, Indonesia \\ Menur Pumpungan No 30. Kecamatan Sukolilo, Kelurahan Menur Pumpungan, \\ Kota Surabaya (60118) \\ Email: yesacahayaning@stiesia.ac.id
}

\begin{abstract}
ABSTRAK
Tujuan dari penelitian ini adalah untuk menguji dan menganalisis Pengaruh Struktur Modal, Profitabilitas, Pertumbuhan Perusahaan dan Nilai Perusahaan serta Free Cash Flow sebagai variabel pemoderasi. Populasi dalam penelitian ini adalah perusahaan Freeport yang terdaftar di FCX. Teknik penentuan sampel dilakukan dengan menggunakan teknik purposive sampling, berdasarkan kriteria tertentu yaitu mempublikasikan laporan keuangan per 31 Desember yang lengkap secara berturut-turut terutama pada tahun 2004 - 2019 Perusahaan yang selalu membagikan dividen secara berturut-turut selama 2004 - 2016. Sumber data yang digunakan adalah data sekunder yang diperoleh dari Laporan Tahunan di FCX Global America (Online). Pengujian hipotesis penelitian menggunakan teknik analisis regresi linier berganda dan MRA Residual. Hasil penelitian menunjukkan bahwa: 1) Struktur Modal tidak berpengaruh signifikan terhadap Nilai Perusahaan, 2) Profitabilitas tidak berpengaruh signifikan terhadap Nilai Perusahaan, 3) Pertumbuhan Perusahaan berpengaruh signifikan terhadap Nilai Perusahaan, 4) Free Cash Flow tidak dapat secara signifikan memoderasi Pengaruh Struktur Modal, Profitabilitas, dan Pertumbuhan Perusahaan terhadap Nilai Perusahaan.
\end{abstract}

Kata kunci: Free Cash Flow; Nilai Perusahaan; Pertumbuhan Perusahaan; Profitabilitas; dan Struktur Modal

\begin{abstract}
The purpose of this study was to examine and analyze the influence of capital structure, profitability, company growth and company value and free cash flow as moderating variables. The population in this study is the Freeport company which is registered with the FCX. The sampling technique was carried out using a purposive sampling technique, based on certain criteria, namely publishing complete financial reports as of December 31st consecutively, especially in 2004 2019 Companies that always pay dividends consecutively during 2004 - 2016. The data sources used is secondary data obtained from the Annual Report at FCX Global America (Online). Testing the research hypothesis using multiple linear regression analysis techniques and residual MRA. The results showed that: 1). Capital Structure has no significant effect on Corporate Value, 2). Profitability has no significant effect on Corporate Value, 3). Company growth has a significant effect on Corporate Value, 4). Free cash flow cannot significantly moderate the influence of capital structure, profitability and company growth on Corporate Value.
\end{abstract}

Keywords: Capital Structure; Company Growth; Corporate Value; Free Cash Flow; and Profitability 


\section{PENDAHULUAN}

Persaingan usaha dalam pergerakan pendanaan yang berbentuk investasi pasar modal serta instrument keuangan pada masa globalisasi sangat bersifat multidimensi serta dinamis, sehingga akan mempengaruhi pada perkembangan model bisnis yang pada prinsipnya untuk memindahkan portofolio investasinya dari satu industri ke industri yang lain sehingga berakibat pada loyalitas investor, dimana investor bakal gampang goyah serta akan meragukan akan keahlian perkembangan industri. Keahlian tersebut menggambarkan nilai industri sehingga akan membagikan sinyal positif dan berakibat pada harga saham serta tingkatan fluktuasi harga minyak mentah dunia yang jadi tantangan industri migas nasional, regional serta global. Setelah dilakukan beberapa revisi pada beberapa tahun kemudian melalui transformasi prosedur kerja, inovasi, reorganisasi, optimalisasi struktur anggaran, kenaikan kompetensi serta energi saing karyawan dan juga penguatan budaya industri (Kumala dewi, et al, 2018).

Utang maupun ekuitas salah satu elemen modal yang bernilai untuk industri, apabila suatu industri menginginkan perkembangan dalam bisnisnya. Elemen modal menggambarkan struktur modal serta pula bagaikan sumber dana karna baik buruknya proporsi hutang serta modal yang berdampak langsung terhadap posisi keuangan industri yang pada kesimpulannya pengaruhi nilai industri. Kesalahan dalam membetulkan struktur modal bakal memiliki akibat yang luas sangat utama apabila industri sangat besar dalam menggunakan hutang, hingga beban wajib ditanggung industri. Struktur modal (capital structure) itu sendiri berasal dari sumber dana modal sendiri maupun modal asing dalam bentuk utang selanjutnya apabila rasio utang di dasarkan pada tingkatan sasaran sampai industri mendapatkan modal dengan menerbitkan utang dalam mencapai tingkatan sasaran sampai digunakan melalui ekuitas maupun dapat memaksimalkan harga saham industri, kedua dana ini yakni dana yang berasal dari eksternal industri yang dapat mempengaruhi nilai industri. Struktur modal diukur dengan mengenakan Debt to Equity Ratio (DER) dimana terus jadi paling atas rasio ini berarti menampilkan struktur pemodalan usaha lebih banyak memakai hutang dari pada modal sendiri (Brigham \& Houston, 2013; Sartono \& Sri Asih, 2013)

Bila industri menampilkan keahlian suatu industri dalam mendanai sesuatu operasional industri serta melunasi sesuatu kewajiban jangka pendeknya hingga industri dalam kondisi Likuiditas. Likuiditas digunakan untuk menganalisis serta menginterpretasikan posisi keuangan jangka pendek, Model likuidasi ialah model evaluasi industri dengan memakai asumsi kalau industri tidak lagi memiliki going concern serta likuidasi. Sesuatu manajer industri sanggup melaksanakan perencanaan serta pengendalian aktiva dengan mudah serta 
hutang lancarnya agar meminimalkan resiko ketidakmampuan industri dalam memenuhi hutang lancarnya, bila jumah aktiva lancarnya tidak balance dengan hutang maka wajib dibayar, jika tidak membayarkan hutangnya maka menimbulkan munculnya financial distress. Sehingga industri dinilai dengan asumsi seluruh peninggalan industri yang bisa dijual sampai adanya proses direalisasikan proses likuidasi, sehingga industri yang mempunyai tingkatan likuiditas yang besar akan cenderung tidak memakai pembiayaan dari hutang. Evaluasi dengan model likuidasi ialah evaluasi konservatif yang dasar perhitungannya dibentuk dengan anggapan kalau peninggalan- peninggalan industri wajib dapat dijual serta direalisasikan jadi kas buat melunasi kewajiban- kewajiban industri. Likuiditas industri bisa diukur lewat rasio keuangan semacam: current ratio, quick ratio serta cash acid- ratio. Sehingga Current ratio acapkali dijadikan bagaikan dimensi likuiditas, tercantum dalam persyaratan kontrak kredit serta akan menampilkan kalau likuiditas mempunyai ikatan yang positif dengan kebijakan dividen (Pratama, 2018; Suharli, 2007; Susantika \& Mahfud, 2019).

Kualitas kinerja manajemen suatu perusahaan itu baik dapat dilihat dari meningkatnya sistem pengelolaan sumber dana operasional secara efektif sehingga dapat menghasilkan laba bersih suatu perusahaan dan akan berdampak pada pemegang saham berupa pengembalian ekuitas sehingga dalam rasio perusahaan disebut dengan return on equity (ROE) yang sering disebut dengan rate of return on net worth.

Mutu kerja manajemen yang baik dapat meningkatkan perkembangan industri yang menggambarkan salah satu aspek yang pengaruhi penentuan kebijakan dividen. Industri yang perkembangan cepat, memerlukan dana yang besar buat membiayai perkembangan industri sehingga laba industri yang ditahan terus menjadi besar yang maksudnya terus menjadi rendah dividen payout ratio serta data yang disediakan oleh industri tentang perkembangan industri akan direspon dengan positif oleh para investor. Dari sudut pandang investor, tingginya tingkatan perkembangan sesuatu industri yang mempunyai aspek menguntungkan sehingga para investor juga tertarik untuk melaksanakan investasi sehingga akan tingkatkan harga saham serta nilai industri juga akan bertambah (Jemani \& Erawati, 2020; Kusumaningtyas, Dewi, \& Chomsatu, 2018)

Pada riset ini mengambil permasalahan tentang PT Freeport Indonesia (PTFI) yang beroperasi di wilayah dataran besar di Kabupaten Mimika Provinsi Papua, menggambarkan salah satu penghasil tunggal tembaga serta emas terbanyak di dunia, serta mempunyai kandungan cadangan tembaga serta cadangan tunggal emas yang bisa diambil serta terbanyak di dunia. Grasberg terletak di jantung suatu daerah mineral yang sangat melimpah, di mana aktivitas eksplorasi yang bersinambung membuka kesempatan untuk terus menaikkan 
cadangan kami yang berumur panjang. PT. Freeport Indonesia pula memasarkan konsentrat yang memiliki tembaga, emas serta perak ke segala penjuru dunia dengan begitu industri mempunyai tujuan yang jelas dalam perihal mendirikan suatau industri di indonesia, sehingga dalam perihal ini telah mempunyai tujuan awal merupakan buat menggapai keuntungan yang optimal (Freeport, n.d.).

Kasus antara PT Freeport Indonesia dengan Pemerintah Indonesia terus bergulir, karena Freeport menolak mengubah statusnya dari Kontrak Karya (KK) dengan Izin Usaha Pertambangan Khusus (IUPK). Pihak Freeport di Amerika serikat yang identik dengan industri tambang dengan adanya kebijakan pergantian status yang ada di Indonesia memberatkan industri karena diharuskan membayar pajak lebih banyak dan memberikan saham (divestasi) sebanyak 51\% ke pemerintah Indonesia. Permasalahan ini tampaknya cukup berdampak pada kinerja saham Freeport-McMoRan Inc, induk usaha Freeport Indonesia yang tercatat di bursa New York Stock Exchange (NYSE). Saham dengan kode FCX ini merosot 1,06 persen dan angka prosentase itu merupakan titik terendah harga saham sejak diberlakukannya larangan ekspor mineral konsentrat pada 12 Januari 2017 ke tingkatan 14,91 dolar AS per saham. Sehingga dengan adanya kasus ini pemerintah menerbitkan PP Nomor 1 Tahun 2017 yang berisikan mewajibkan Freeport harus mengubah status dari Kontrak Karya (KK) menjadi Izin Usaha Pertambangan Istimewa (IUPK), serta harus mematuhi syarat industri bisa melakukan ekspor apabila berkomitmen membangun smelter dalam jangka 5 tahun pada Peraturan Menteri ESDM Nomor 5 Tahun 2017. Adanya perubahan peraturan pemerintah yang diberlakukan menyebabkan pengaruh penentuan kebijakan dividend dan tingkatan perkembangan industry akan mutu manajemen dalam membangun pabrik pemurnian maupun smelter. Perusahaan yang akan melakukan perkembangan khususnya sektor industry akan memerlukan dana yang cukup besar dalam membiayai perkembangan sehingga laba industri yang ditahan terus menjadi besar dan menghasilkan tingginya dividen payout ratio kemudian direspon dengan positif oleh para investor. Jika dinilai dari sudut pandang investor dengan adanya peningkatan aspek perkembangan industri yang menguntungkan akan berdampak pada para investor tertarik untuk melakukan investasi, sehingga akan berdampak pada tingkatkan harga saham serta nilai perusahaan juga akan bertambah (Freeport, n.d.).

Pada 12 Januari 2017, saham Freeport turun tajam 3, 78 persen ke 15, 27 dolar AS per saham dari hari tadinya sebesar 15, 87 dolar AS per saham. Ini menampilkan larangan ekspor langsung berakibat pada pergerakan sahamnya. Semenjak 12 Januari sampai hari ini, pergerakan saham Freeport memanglah dalam tren turun dengan penyusutan rata- rata 2, 36 
persen. Pergerakannya pula berkisar di tingkat 14,91- 17,02 dolar Amerika Serikat( AS) per saham. Sehingga Freeport- McMoRan Inc tidak bisa penuhi kriteria kedua serta ketiga dari tujuan pendirian industri ialah mau memakmurkan owner industri ataupun para owner saham serta mengoptimalkan nilai industri yang tercermin pada harga saham, disebabkan PT Freeport Indonesia tidak mempunyai 51 persen saham dari Freeport- McMoRan Inc (Freeport, n.d.).

Pemerintah serta PT Freeport Indonesia( PTFI) sampai dikala ini belum menemui titik temu divestasi saham Freeport sebesar 10, 64\%. Semenjak April kemudian, hingga dikala ini belum terdapat kemajuan berarti pelepasan saham industri asal Amerika Serikat( AS) tersebut sebab perbandingan perhitungan besaran divestasi. Pemerintah mengenakan perhitungan dengan tata cara cost replacement yang setelah itu diganti oleh pihak Freeport memakai tata cara fear value. Kedua pihak mempunyai hitungan tiap- tiap menimpa harga yang dinilai fair buat saham tersebut. Dikala ini, pemerintah sudah mempunyai saham Freeport sebanyak 9, $36 \%$ serta berikutnya akan membeli 10, 64\% saham raksasa tambang AS itu lagi supaya jatah kepemilikan Indonesia menggapai 20\%. Divestasi saham dicoba secara bertahap sampai pada kesimpulannya pemerintah mempunyai $51 \%$ saham Freeport. Freeport sendiri menawarkan harga 10, 64\% saham divestasi sebesar USD 1,7 miliyar. Pemerintah menyangka harga tersebut masih lumayan mahal, sebab dari hitungan pemerintah biayanya mendekati USD 630 juta (Freeport, n.d.)

Bersumber pada riset Wahyuni et al (2017) yang berjudul pengaruh intellectual capital terhadap nilai perusahaan dengan free cash flow sebagai variabel moderating, objek riset ini menggunakan analisis empiris pada perusahaan yang terdaftar di bursa efek indonesia. hasil dari variabel VACA, VAHU dapat mempengaruhi secara signifikan terhadap nilai perusahaan, dan sebaliknya variable STVA tidak dapat mempengaruhi secara signifikan terhadap nilai perusahaan. Arus kas leluasa bagaikan variabel moderat tidak signifikan pengaruhi ikatan STVA dengan nilai perusahaan. Sebaliknya dari riset Putra (2017) yang berjudul Free Cash Flow sebagai Pemoderasi Pengaruh Earnings Management Serta Kebijakan Dividen Pada Nilai Perusahaan, dimana menghasilkan Earnings management berpengaruh negatif dan signifikan terhadap nilai perusahaan, Kebijakan dividen berpengaruh negatif dan signifikan terhadap nilai perusahaan, Free cash flow dapat memperlemah pengaruh earnings management dan kebijakan dividen terhadap nilai perusahaan. Sehingga bisa dismpulkan kalau free cash flow ialah laba bersih industri yang memanglah berarti, 
namun arus kas apalagi lebih berarti lagi sebab dividen yang wajib dibayarkan secara tunai serta sebab kas dibutuhkan buat membeli aktiva yang diperlukan buat melanjutkan pembedahan industri (Eugene F. Brigham and Joel F. Houston, 2015). Arus kas tidak bisa dipertahankan terus- menerus kecuali bila aktiva senantiasa yang didepresiasi ditukar serta bahan- bahan baru dibesarkan, sehingga manajemen bukanlah seluruhnya leluasa memakai arus kas semaunya sendiri

Free cash flow menarik digunakan sebagai variable moderasi antara Struktur Modal, Profitabilitas, dan Pertumbuhan Perusahaan terhadap Nilai Industri dalam riset ini, sebab bersumber pada riset tadinya arus kas leluasa (free cash flow) memiliki hasil yang tidak signifikan serta memperlemah pada disaat di moderasi, pada prinsipnya arus kas bebas (free cash flow) ada nilai dari pembedahan suatu industri yang sangat tergantung pada segala arus kas leluasa yang diharapkan di masa mendatang dengan metode melaksanakan analisis fundamental terhadap laporan keuangan dua ataupun tiga tahun kebelakang, sehingga akan mengenali seberapa besar laba yang didapatkan sesudah pajak dikurangi jumlah investasi pada modal kerja serta aktiva senantiasa yang diperlukan untuk mempertahankan bisnis. Jadi, arus kas yang baik akan mencerminkan kas yang digunakan untuk didistribusikan kepada para investor setelah itu industri menempatkan segala investasinya pada aktiva, produk- produk baru, serta modal kerja yang diperlukan buat mempertahankan sistem pembedahan yang lagi berjalan (Eugene F. Brigham and Joel F. Houston, 2015). Karenanya, salah satu metode untuk para manajer membuat industri jadi lebih bernilai dengan tingkatkan arus kas bebas.

Penelitian ini bertujuan untuk menguji apakah struktur modal, profitabilitas dan Pertumbuhan Perusahaan berpengaruh terhadap nilai perusahaan dan apakah free cash flow mampu memoderasi pengaruh Struktur Modal, Profitabilitas dan Pertumbuhan Perusahaan terhadap nilai perusahaan.

\section{Struktur modal}

Teori struktur modal merupakan perpaduan antara hutang dan ekuitas dalam jangka panjang perusahaan yang bersifat permanen, struktur modal itu sendiri bisa didapat dari memaksimumkan harga saham perusahaan dari peredaran saham preferen dan saham biasa. Struktur modal dalam hal ini diproksikan dengan Debt to Equity Ratio (DER), Ratio ini dapat menggambarkan tingkat risiko tidak tertagihnya hutang dalam struktur modal yang dimiliki perusahaan (Dewi Teresia \& Hermi, 2016; Ramadhani \& Maryam, 2018). 


\section{Profitabilitas}

Profitabilitas merupakan pengelolaan kinerja manajemen dalam hal laba perusahaan dan dapat diukur menggunakan berbagai kriteria seperti laba operasi, laba bersih, tingkat pengembalian investasi atau aktiva, dan tingkat pengembalian ekuitas (Mukhlasin, 2002). Dalam hal ini rasio profitabilitas diukur dengan return on equity (ROE), rasio ini mengukur kemampuan perusahaan dalam menghasilkan laba bersih untuk pengembalian ekuitas pemegang saham. Jika semakin besar hasil ROE maka kinerja suatu perusahaan semakin baik (Sri, 2013)

\section{Pertumbuhan perusahaan}

Memprediksi sejauh mana perkembangan perusahaan dalam menempatkan dirinya dalam suatu sistem ekonomi dalam persaingan antar perusahaan yang sama itu yang dimanakan pertumbuhan (growth). Suatu Pertumbuhan perusahaan memiliki indikator untuk melakukan penilaian sehingga perusahaan dapat menilai kemampuan perusahaan dalam mempertahankan sistem manajemennya serta mempertahankan pertumbuhan perekonomian dalam sektor usahanya (Dewi Teresia \& Hermi, 2016; Suastini et al, 2016).

\section{Free cash flow}

Free Cash Flow berasal dari operasional modal kerja (working capital) atau investasi pada aktiva tetap (fixed assets) yang tidak dikelola maka dapat dialokasikan kepada pemegang saham. Dalam memutuskan kegiatan operasional berjalan dengan baik yang berasal dari aktiva tetap dan modal kerja diperlukan pertimbangan yang jelas dari manajemen, sehingga manajemen tidak sepenuhnya bebas menggunakan arus kas secara bebas (Brigham \& Houston, 2010).

\section{Nilai Perusahaan}

Nilai perusahaan menentukan nilai pasar dengan surat berharga dari utang dan ekuitas perusahaan yang beredar yang dapat digunakan sebagai persepsi investor terhadap tingkat keberhasilan perusahaan yang sering dikaitkan dengan harga saham yang merupakan keinginan pemilik perusahaan, karena nilai pemegang saham yang tinggi menunjukkan kekayaan pemegang saham (Jemani \& Erawati, 2020; Keown, et al, 2014). Dalam hal ini nilai perusahaan di proksikan dengan Price To Book Value (PBV) yang dapat memberikan gambaran berapa kali kita membayar sebuah saham dengan nilai buku perusahaan, dengan cara membandingkan harga per saham dengan nilai buku per saham. (Brigham \& Houston, 2013). 


\section{HIPOTESIS}

\section{Pengaruh struktur modal terhadap nilai perusahaan}

Teori struktur modal merupakan hutang jangka panjang terdapat pada hutang dan ekuitas yang berupa saham beredar, sehingga dapat memaksimumkan harga saham suatu perusahaan dan akan menimbulkan struktur modal yang dapat mengoptimalkan Debt to Equity Ratio (DER). Rasio ini mengukur seberapa besar perusahaan dibiayai oleh hutang. Jika tingkat DER lebih menghasilkan utang yang tinggi maka akan terjadi risiko perusahaan sehingga akan berdampak pada nilai perusahaan. Dalam hal ini nilai perusahaan di proksikan dengan Price To Book Value (PBV) yang merupakan rasio yang membandingkan antara harga per saham dengan nilai buku per saham (Ramadhani \& Maryam, 2018).

Berdasarkan penelitian Jemani, (2020) Struktur modal memiliki dampak positif dan signifikan terhadap nilai perusahaan. Struktur modal terkait dengan pemilihan sumber pembiayaan internal dan eksternal untuk perusahaan dan memiliki dampak signifikan pada nilai perusahaan. Sumber dana untuk perusahaan adalah dana yang dihasilkan oleh perusahaan, seperti laba ditahan dan depresiasi. Dana hutang berasal dari kreditor dan merupakan hutang perusahaan.

H1: Struktur modal berpengaruh positif terhadap nilai perusahaan

\section{Pengaruh profitabilitas terhadap nilai perusahaan}

Profitabilitas untuk mengukur tingkat laba perusahaan berdasarkan hasil pengembalian dari tingkat penjualan dan tingkat investasi, sehingga akan meningkatkan nilai suatu perusahaan dan indikator itu dapat menjadi rujukan dalam persepsi investor terhadap tingkat keberhasilan perusahaan yang sering dikaitkan dengan harga saham yang merupakan keinginan pemilik perusahaan, karena nilai pemegang saham yang tinggi menunjukkan kekayaan pemegang saham.

Berdasarkan penelitian Sri, (2013) maka profitabilitas berpengaruh positif dan signifikan terhadap nilai perusahaan, dimana semakin besar tingkat capaian profitabilitas perusahaan maka akan meningkatkan proporsi hutang dalam struktur pendanaan perusahaan yang akan mengakibatkan semakin tinggi peluang pertumbuhan dan semakin besar pula nilai perusahaan tersebut.

H2: Profitabilitas berpengaruh positif terhadap nilai perusahaan

\section{Pengaruh pertumbuhan perusahaan terhadap nilai perusahaan}

Pertumbuhan (growth) sendiri sebagai indikator investor menilai seberapa jauh perusahaan menempatkan sistem ekonomi secara keseluruhan untuk mencerminkan kemampuan perusahaan dalam mempertahankan manajemennya dan pertumbuhan 
perekonomi dalam sektor usahanya. Jika manajemen perusahaan mempunyai proses kualitas standar mutu yang baik dalam suatu pertumbuhan perusahaan akan membuat nilai perusahaan menjadi baik juga. Nilai pasar suatu ekuitas perusahaan ditambah dengan nilai pasar hutang atau penambahan dari jumlah ekuitas perusahaan dengan hutang perusahaan dapat mencerminkan nilai perusahaan.

Berdasarkan hasil penelitian Suastini et al, (2016) maka Pertumbuhan perusahaan mempunyai pengaruh positif dan signifikan terhadap nilai perusahaan. Dari hasil tersebut mempunyai evaluasi tingginya pertumbuhan perusahaan maka akan menaikkan nilai perusahaan, sehingga terjadinya prospek yang baik bagi perusahaan. Hal ini tentu akan direspon positif oleh para investor sehingga akan berpengaruh pada peningkatan harga saham dan akan berdampak pada peningkatan nilai perusahaan.

H3: Pertumbuhan perusahaan berpengaruh positif terhadap nilai perusahaan

\section{Pengaruh free cash flow pada hubungan struktur modal, profitabilitas dan} pertumbuhan perusahaan dengan nilai perusahaan

Arus kas bebas yang tersedia di perusahaan berkaitan dengan struktur modal yang dapat mengoptimalkan antara hutang dan ekuitas, sehingga dapat dialokasikan dalam bentuk dividen atau dapat dialokasikan untuk perlunasan hutang agar terhindar dari tindakan manajer dalam berinvestasi yang memungkinkan hasil net present value negatif. Jika free cash flow dalam perusahaan itu tinggi maka membuat manajer berada di bawah tekanan pemegang saham untuk membagikan kelebihan kas tersebut dalam bentuk dividen. Dengan kata lain, kebijakan dividen diambil jika perpengaruh sangat tinggi khususnya bagi free cash flow perusahaan (Putra, 2017).

H4: Free Cash Flow mampu memoderasi pengaruh struktur modal, profitabilitas dan pertumbuhan perusahaan terhadap nilai perusahaan

\section{METODE PENELITIAN}

Metode penelitian ini menggunakan model analisis teknik analisis regresi linier berganda dan MRA Residual.

\section{Teori Data Statistik}

\section{Uji Hipotesis pertama, kedua, ketiga menggunakan Regresi Berganda}

Untuk menunjukkan tingkat signifikansi pengaruh masing-masing variabel bebas terhadap variabel terikatnya yang digunakan dalam analisis regresi linier berganda. pada penelitian ini hubungan antara "struktur modal, profitabilitas dan pertumbuhan perusahaan terhadap nilai perusahaan” yang di tunjukkan oleh pada Gambar 1. 


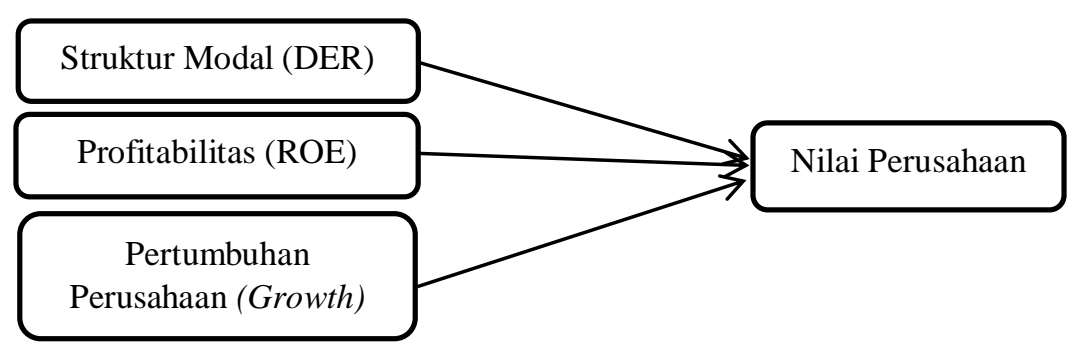

\section{Gambar 1. Nilai perusahaan sebagai fungsi dari struktur modal, profitabilitas dan pertumbuhan perusahaan}

Dari Gambar 1 maka persamaan Regresi Berganda adalah sebagai berikut:

Nilai Perusahaan $=\beta_{0}+\beta_{1}$ Struktur modal $+\beta_{2}$ Profitabilitas $+\beta_{3}$ Pertumbuhan Perusahaan

\section{Uji Hipotesis keempat meggunakan Uji Residual}

Uji Hipotesis keempat meggunakan Uji Residual biasa disebut dengan Variabel moderating adalah menganailis untuk menguatkan atau memperlemah hubungan antara variabel independen dengan variabel dependen dan untuk membuktikan bahwa variabel moderating tersebut menjadi variabel mediasi atau tidak. Sebagaimana dalam kerangka konseptual yang mengambarkan hubungan antara "struktur modal, profitabilita dan pertumbuhan perusahaan, free cash flow dan nilai perusahaan" pada gambar 2.

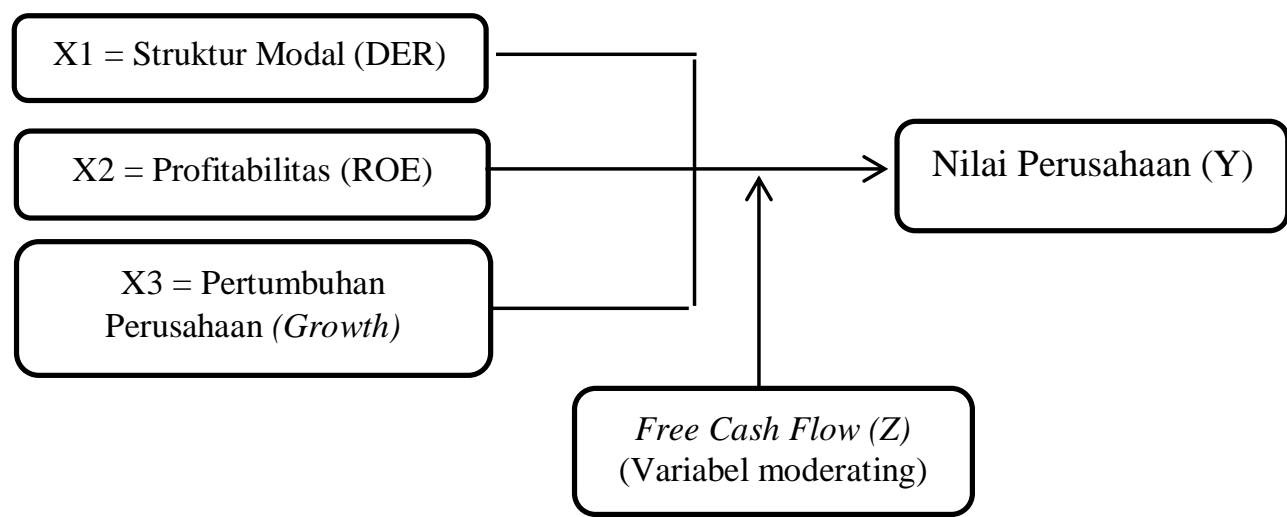

\section{Gambar 2. Hubungan struktur modal, Profitabilitas, Pertumbuhan Perushaaan, free cash flow dan Nilai Perusahaan}

Langkah uji residual dapat digambarkan dengan persamaan regresi sebagai berikut (Ghozali, 2009):

1. Melakukan regresi

Free cash flow $=\mathrm{b}_{0}+\mathrm{b}_{1}$ Struktur modal $+\mathrm{b}_{2}$ Profitabilitas $+\mathrm{b}_{3}$ Pertumbuhan Perusahaan $+\mathrm{e}(1)$

2. Mencari residual persamaan (1) dan meregresikan dengan Nilai Perusahaan.

$|\mathrm{e}|=\mathrm{b}_{0}+\mathrm{b}_{1}$ Nilai Perusahaan 
Analisis residual ingin menguji "pengaruh deviasi (penyimpangan) dari suatu model. Fokusnya adalah ketidak cocokkan (Lack of fit) yang dihasilkan dari deviasi hubungan linier variabel independen. Lack of fit ditunjukkan oleh nilai residual didalam regresi. Dalam hal ini jika terjadi kecocokkan antara struktur modal, profitabilitas, pertumbuhan perusahaan, dan free cash flow (Nilai residual kecil atau nol) yaitu struktur modal, profitabilitas, pertumbuhan perusahaan tinggi dan free cash flow juga tinggi, maka nilai perusahaan juga tinggi”. lack of fit terjadi jika rendahnya nilai perusahaan akan mengakibatkan struktur modal, profitabilitas, pertumbuhan perusahaan tinggi dan free cash flow rendah.

Persamaan regresi (2) menjabarkan "apakah variabel free cash flow merupakan variabel moderating" dan ini ditunjukkan pada hasil nilai koefisien $b_{1}$ nilai perusahaan signifikan dan negatif, terlihat pada hasil Lack of fit antara "struktur modal, profitabilitas, pertumbuhan perusahaan dan free cash flow berpengaruh negatif pada nilai perusahaan”.

\section{Populasi Penelitian}

Populasi riset ini merupakan industri Freeport yang terdaftar di FCX. Metode penentuan sampel menggunakan metode purposive sampling. Purposive sampling bersumber pada kriteria tertentu dari publikasi laporan keuangan per 31 Desember yang lengkap secara berturut-turut paling utama pada tahun 2004-2019 dan perusahaan membagikan dividen secara berturut-turut sepanjang 2004-2019 serta bersumber pada pertimbangan tertentu semacam kriteria populasi (Notoatmodjo, 2017; Sugiono, 2014). Sumber informasi yang digunakan merupakan informasi sekunder yang diperoleh dari Laporan Tahunan di FCX Global America (Online).

Kriteria-kriteria yang digunakan pada penelitian ini adalah:

1. Sampel yang akan dipilih adalah perusahaan Freeport Indonesia.

2. Mempublikasikan laporan keuangan per 31 Desember yang lengkap secara berturut-turut terutama pada tahun 2004-2019.

3. Perusahaan yang selalu membagikan dividennya secara berturut-turut selama tahun 20042019.

4. Sampel yang akan dipilih adalah laporan keuangan perusahaan Freeport Indonesia yang dinyatakan dalam dollar (karena di publikasikan oleh FCX Global Amerika).

\section{HASIL DAN PEMBAHASAN}

\section{Pengujian Asumsi Klasik}

Apakah hasil prediksi perhitungan regresi yang dilakukan valid bebas dari adanya gejala autokorelasi, gejala multikolinearitas, dan gejala heteroskedastisitas dan telah memenuhi 
persyaratan BLUES (best linear unbiased estimator) disebut pengujian asumsi klasik. dilakukan sebagai berikut:

\section{Uji Normalitas}

Uji Normalitas merupakan "suatu alat uji yang digunakan untuk menguji apakah dari variabel-variabel yang digunakan dalam model regresi mempunyai distribusi normal atau tidak. Untuk mengetahui apakah data tersebut berdistribusi normal, dapat diuji dengan metode Kolmogorov Smirnov maupun pendekatan grafik".

\section{Pendekatan Kolmogorov Smirnov}

Berdasarkan hasil Uji Normalitas yang telah dilakukan diperoleh hasil sebagai berikut:

Tabel 1. Hasil Uji Normalitas

\section{One-Sample Kolmogorov-Smirnov Test}

Unstandardized Residual

\begin{tabular}{llr}
\hline $\mathrm{N}$ & & 16 \\
\hline Normal Parameters ${ }^{\mathrm{a}, \mathrm{b}}$ & Mean & $0 \mathrm{E}-7$ \\
& Std. Deviation & 153,68265193 \\
& Absolute &, 125 \\
Most Extreme Differences & Positive &, 117 \\
& Negative &,- 125 \\
Kolmogorov-Smirnov Z & &, 501 \\
Asymp. Sig. (2-tailed) & &, 963 \\
\hline
\end{tabular}

Berdasarkan pada tabel di atas besarnya nilai Asymp sig (2-tailed) sebesar 0,963 > 0,050, hal ini berdasarkan syarat yang telah ditetapkan dapat diputuskan bahwa data tersebut berdistribusi normal dan dapat digunakan dalam penelitian ini.

\section{Pendekatan Grafik}

Pendekatan kedua ini merupakan pendekatan grafik menggunakan syarat grafik Normal P-P (Plot of regresion standard) harus mengikuti ketentuan garis diagonal antara 0 dan pertemuan sumbu X dan Y. Garfik normalitas disajikan dalam gambar berikut:

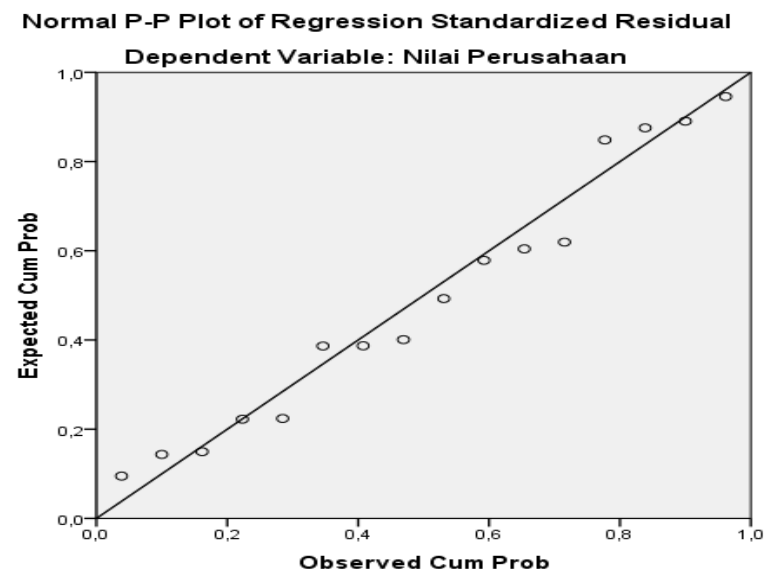

Gambar 3. Grafik Pengujian Normalitas Data 
Dari hasil grafik diatas disimpulkan data penelitian ini telah berdistribusi normal dan dapat disimpulkan pendekatan Kolmogorov Smirnov maupun pendekatan grafik model regresi telah memenuhi asumsi normalitas, dengan alasan mengikuti garis diagonal antara 0 (nol) dengan pertemuan sumbu Y (Expected Cum. Prob.)

\section{Uji Multikolinearitas}

Uji multikolinearitas bertujuan untuk menguji apakah model regresi ditemukan adanya korelasi antar variabel bebas (independen), dampak dari uji multikolinearitas ini adanya tingginya variabel pada sampel sehingga mengakibatkan standar error yang besar. Nilai tolerance dan variance inflation factor (VIF) digunakan untuk membuktikan adanya multikolinearitas dengan nilai tolerance $<0.10$ atau sama dengan nilai VIF $>10$ (Ghozali, 2013). Hasil pengujian Multikolinieritas sebagai beikut:

Tabel 2. Nilai Toleran dan Variance Inflation Faktor

\begin{tabular}{lccc}
\hline \multicolumn{1}{c}{ Variabel } & Nilai Tolerance & VIF & Keterangan \\
\hline Struktur Modal & 0,680 & 1,470 & Bebas Multikolinieritas \\
Profitabilitas & 0,659 & 1,517 & Bebas Multikolinieritas \\
$\begin{array}{l}\text { Pertumbuhan } \\
\text { Perusahaan }\end{array}$ & 0,923 & 1,084 & Bebas Multikolinieritas \\
\hline
\end{tabular}

\section{Uji Heteroskedastisitas}

Uji heteroskedastisitas manganalisis apakah model regresi terjadi ketidaksamaan variance dari residual satu observasi ke observasi yang lain. Cara mendeteksi ada atau tidaknya heteroskedastisitas yaitu melihat grafik plot antara nilai prediksi variabel dependen atau membentuk pola tertentu secara beraturan maka menunjukkan terjadinya heteroskedastisitas dan sebaliknya jika tidak ada pola yang beraturan pada titik - titik menyebar di atas dan di bawah angka 0 pada sumbu Y, maka tidak terjadi heteroskedastisitas (Ghozali, 2013). Grafik pengujian Heteroskedaktisitas disajikan berikut:

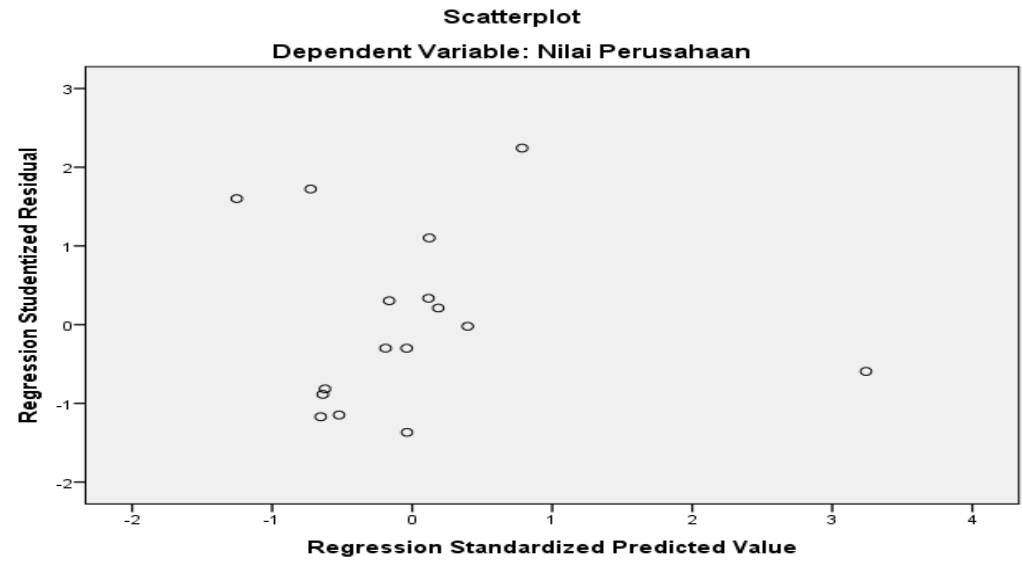

Gambar 4. Heterokedaktisitas pada Regresi Linier Berganda 
Dari gambar di atas menyimpulkan bahwa hasil Heterokedaktisitas dalam penelitian ini menggunakan model regresi dan tidak terjadi gangguan heteroskedastisitas, dikarenakan terlihat titik - titik menyebar secara acak dan tidak membentuk sebuah pola tertentu yang jelas dan titik tersebut tersebar di atas maupun di bawah angka 0 pada sumbu Y.

\section{Uji Autokorelasi}

Uji autokorelasi bertujuan menilai model regresi linear, model ini memiliki gabungan korelasi antara kesalahan pengganggu pada periode t dengan kesalahan pengganggu pada periode t-1 (sebelumnya). Apabila autokorelasi bermasalah maka akan diidentifikasi terjadi korelasi, sehingga Regresi yang benar adalah regresi yang tidak terjadi autokorelasi di dalamnya (Ghozali, 2013).

Hasil pengujian Dalam analisis nilai Durbin Watson diperoleh sebesar 0,791, dimana angka tersebut berada diantara nilai -2 dan +2 membuktikan tidak terjadi gangguan pada normalitas. Demikian juga pada uji asumsi klasik, otokorelasi, multikolinieritas maupun heteroskedaktisitas tidak menunjukkan adanya gangguan dan model analisis penelitian ini layak untuk diregresikan.

\section{Analisis Regresi Linier Berganda}

Analisis regresi linier berganda digunakan "untuk mengetahui seberapa besar pengaruh faktor yang digunakan dalam model penelitian yaitu struktur modal, profitabilitas dan pertumbuhan perusahaan terhadap nilai perusahaan secara linier”.

\section{Tabel 3. Hasil Uji regresi Berganda}

\begin{tabular}{|c|c|c|c|c|c|c|}
\hline \multirow{2}{*}{\multicolumn{2}{|c|}{ Model }} & \multicolumn{2}{|c|}{ Unstandardized Coefficients } & \multirow{2}{*}{$\begin{array}{c}\text { Standardized } \\
\text { Coefficients }\end{array}$} & \multirow[b]{2}{*}{$\mathrm{t}$} & \multirow[t]{2}{*}{ Sig. } \\
\hline & & B & Std. Error & & & \\
\hline \multirow{4}{*}{1} & (Constant) & 474,307 & 121,752 & & 3,896 & ,002 \\
\hline & Struktur Modal &,- 852 & ,633 &,- 330 & $-1,345$ & ,203 \\
\hline & Profitabilitas & $-1,330$ & ,862 &,- 385 & $-1,544$ & , 148 \\
\hline & Pertumbuhan Perusahaan & 2,778 & ,878 & ,666 & 3,163 & ,008 \\
\hline
\end{tabular}

Dari data tabel di atas persamaan regresi yang didapat adalah:

Nilai Perusahaan $=474,307-0,852_{\text {Struktur modal }}-1,33$ Profitabilitas $+2,778_{\text {Pertumbuhan Perusahaan }}$ Dari persamaan regresi di atas dapat diuraikan sebagai berikut:

1. Konstanta $\left(\beta_{0}\right)=474,307$ menunjukkan jika variabel bebas yang terdiri dari struktur modal, likuiditas dan profitabilitas tidak ada perubahan $=0$, maka nilai perusahaan sebesar 474,307 .

2. Koefisien regresi struktur modal $\left(\beta_{1}\right)=-0,852$, Hasil ini menunjukkan kondisi tingginya struktur modal yang diproksi melalui DER akan menurunkan nilai perusahaan, 
dikarenakan berdasarkan hasil koefisien regresi membuktikan hasil hubungan negatif (berlawanan arah) antara variabel struktur modal dengan nilai perusahaan.

3. Koefisien regresi Profitabilitas $\left(\beta_{2}\right)=-1,330$, Hasil ini menunjukkan kondisi ini menunjukkan tingginya tingkat Profitabilitas yang diproksi melalui ROE akan menurunkan nilai perusahaan, dikarenakan berdasarkan hasil koefisien regresi membuktikan hasil hubungan negatif (berlawanan arah) antara variabel Profitabilitas dengan nilai perusahaan.

4. Koefisien regresi Pertumbuhan Perusahaan $\left(\beta_{3}\right)=2,778$, Hasil ini menunjukkan kondisi ini menunjukkan tingginya tingkat pertumbuhan perusahaan yang dimiliki oleh perusahaan akan semakin meningkatkan nilai perusahaan, dikarenakan berdasarkan hasil koefisien regresi membuktikan hasil hubungan positif (searah) antara variabel pertumbuhan perusahaan dengan nilai perusahaan.

\section{Uji Kelayakan Model}

\section{Uji F}

Uji kelayakan model dalam penelitian ini menggunakan uji $\mathrm{F}$ mengetahui variabel struktur modal, likuiditas dan profitabilitas layak atau tidak digunakan dalam model penelitian pada tingkat $\alpha$ sebesar 5\%. Hasil pengujian kelayakan model nampal pada tabel 1 sebagai berikut:

Tabel 4. Anova

\begin{tabular}{llccccc}
\hline Model & & Sum of Squares & Df & Mean Square & F & Sig. \\
\hline \multirow{3}{*}{1} & Regression & 368365,657 & 3 & 122788,552 & 4,159 &, $031^{\mathrm{b}}$ \\
& Residual & 354275,363 & 12 & 29522,947 & & \\
& Total & 722641,020 & 15 & & & \\
\hline
\end{tabular}

Dari tabel diatas terlihat tingkat signifikan yang dihasilkan sebesar 0,031 kurang dari $\alpha$ $=5 \%$ yang menunjukkan model yang digunakan dalam penelitian yaitu struktur modal, profitabilitas dan pertumbuhan perusahaan layak dan dapat dipergunakan analisis berikutnya.

\section{Koefisien Determinasi $\left(\mathbf{R}^{2}\right)$}

Koefisien determinasi digunakan untuk mengetahui prosentase kontribusi variabel struktur modal, profitabilitas dan pertumbuhan perusahaan terhadap nilai perusahaan.

\begin{tabular}{|c|c|c|c|c|c|}
\hline \multicolumn{6}{|c|}{ Tabel 5. Model Summary } \\
\hline Model & $\mathrm{R}$ & R Square & Adjusted R Square & $\begin{array}{l}\text { Std. Error of the } \\
\text { Estimate }\end{array}$ & Durbin-Watson \\
\hline 1 &, $714^{\mathrm{a}}$ & ,510 & ,387 & 171,82243 & ,791 \\
\hline
\end{tabular}

Dari tabel di atas diketahui $\mathrm{R}$ square $\left(\mathrm{R}^{2}\right)$ sebesar 0,510 yang menunjukkan sumbangan atau kontribusi dari model yang digunakan penelitian terhadap nilai perusahaan sebesar $51 \%$. Sedangkan sisanya $(100 \%-51 \%=49 \%)$ dikontribusi oleh faktor lainnya. 
Sedangkan tingkat keeratan hubungan model yang digunakan penelitian terhadap nilai perusahaan ditunjukkan dengan $(\mathrm{R})$ sebesar 0,714 yang memperlihatkan hubungan antara model tersebut terhadap nilai perusahaan sebesar $71,4 \%$ dan dapat dikatakan erat.

\section{Uji Hipotesis, Pertama, Kedua Dan Ketiga (Uji t)}

Uji hipotesis ini menggunakan uji t, hipotesisi ini digunakan untuk membuktikan variabel struktur modal, profitabilitas dan pertumbuhan perusahaan yang memiliki pengaruh terhadap variabel nilai perusahaan. Hasil pengujian yang telah dilakukan dapat diihat pada tabel 3 sebagai berikut:

Tabel 6. Hasil Perolehan Tingkat Signifikan

\begin{tabular}{lccc}
\hline \multicolumn{1}{c}{ Variabel } & Koefisien Regresi & Sig & Keterangan \\
\hline Struktur Modal & $-0,852$ & 0,203 & Tidak Signifikan \\
Profitabilitas & $-1,330$ & 0,148 & Tidak Signifikan \\
Pertumbuhan Perusahaan & 2,778 & 0,008 & Signifikan \\
\hline
\end{tabular}

Dari tabel diatas dapat dijelaskan sebagai berikut:

1. Hasil Uji Pengaruh dari Variabel Struktur Modal Terhadap Nilai Perusahaan

Dari hasil pengujian uji t pada tabel di atas menghasilkan tingkat signifikan variabel struktur modal $=0,203<\alpha=0,050$ (level of signifikan), sehingga hasil ini menunjukkan adanya pengaruh dari variabel struktur modal tersebut terhadap nilai perusahaan adalah tidak signifikan dan negatif.

2. Hasil Uji Pengaruh dari Variabel Profitabilitas Terhadap Nilai Perusahaan

Dari hasil pengujian uji t pada tabel di atas menghasilkan tingkat signifikan variabel profitabilitas $=0,148<\alpha=0,050$ (level of signifikan), sehingga hasil ini menunjukkan adanya pengaruh variabel profitabilitas tersebut terhadap nilai perusahaan adalah tidak signifikan dan negatif.

3. Hasil Uji Pengaruh dari Variabel Pertumbuhan Perusahaan Terhadap Nilai Perusahaan

Dari hasil pengujian uji t pada tabel di atas menghasilkan tingkat signifikan variabel Pertumbuhan Perusahaan $=0,008>\alpha=0,050$ (level of signifikan), sehingga hasil ini menunjukkan adnaya pengaruh variabel pertumbuhan perusahaan tersebut terhadap nilai perusahaan adalah signifikan dan positif.

\section{Koefisien Determinasi Partial $\left(\mathbf{r}^{2}\right)$}

Koefisien determinasi parsial ini digunakan untuk mengetahui faktor manakah yang paling berpengaruh dari variabel struktur modal, likuiditas dan profitabilitas terhadap nilai perusahaan. 
Tabel 7. Koefisien Korelasi dan Determinasi Parsial

\begin{tabular}{lcc}
\hline \multicolumn{1}{c}{ Variabel } & $\mathrm{R}$ & $\mathrm{r}^{2}$ \\
\hline Struktur Modal & $-0,362$ & 0,1310 \\
Profitabilitas & $-0,407$ & 0,1656 \\
Pertumbuhan Perusahaan & 0,674 & 0,4543 \\
\hline
\end{tabular}

Dari korelasi parsial diatas maka dapat diperoleh koefisien determinasi parsial dengan penjelasan sebagai berikut:

1. Kontribusi variabel struktur modal tersebut terhadap nilai perusahaan Freeport Indonesia sebesar 13,10\%, hal ini ditunjukkan koefisien determinasi korelasi parsial sebesar 0,1310.

2. Kontribusi variabel profitabilitas tersebut terhadap nilai perusahaan Freeport Indonesia sebesar 16,56\%, hal ini ditunjukkan koefisien determinasi korelasi parsial sebesar 0,1656.

3. Kontribusi variable Pertumbuhan Perusahaan tersebut terhadap nilai perusahaan Freeport Indonesia sebesar 45,43\%, hal ini ditunjukkan koefisien determinasi korelasi parsial sebesar 0,4543 .

Dari hasil tersebut di atas dapat disimpulkan bahwa koefisien determinasi partialnya paling besar adalah variabel Pertumbuhan Perusahaan, karena mempunyai pengaruh yang dominan terhadap nilai perusahaan Freeport Indonesia.

\section{Analisis Regresi dengan Variabel Moderating}

\section{Analisis Persamaan 1}

Persamaan 1 digunakan untuk mencari nilai residual antara struktur modal, profitabilitas dan pertumbuhan perusahaan terhadap free cash flow. Adapun hasil dari olahan data tersebut dapat dibuat dalam model persamaan 1, sebagai berikut:

\section{Tabel 8. Koefisien Regresi Persamaan 1}

\begin{tabular}{|c|c|c|c|c|c|c|}
\hline \multirow{2}{*}{\multicolumn{2}{|c|}{ Model }} & \multicolumn{2}{|c|}{ Unstandardized Coefficients } & \multirow{2}{*}{$\begin{array}{c}\text { Standardized } \\
\text { Coefficients } \\
\text { Beta }\end{array}$} & \multirow[t]{2}{*}{$\mathrm{t}$} & \multirow[t]{2}{*}{ Sig. } \\
\hline & & B & Std. Error & & & \\
\hline \multirow{4}{*}{1} & (Constant) & 8,582 &, 705 & & 12,179 & ,000 \\
\hline & Struktur Modal &,- 008 & ,004 &,- 494 & $-2,094$ & 058 \\
\hline & Profitabilitas &,- 017 &, 005 &,- 815 & $-3,400$ &, 005 \\
\hline & Pertumbuhan Perusahaan & 011 & ,005 & ,441 & 2,177 &, 050 \\
\hline
\end{tabular}

\section{Analisis Residual (Persamaan 2)}

Analisis residual berfungsi menguji dihasilkan dari deviasi hubungan linier variabel independen deviasi (penyimpangan) berasal dari menguji adanya ketidak cocokkan (Lack of fit). Adapun hasil dari olahan data tersebut dapat dibuat dalam model persamaan 2, sebagai berikut: 
Tabel 9. Koefisien Regresi Persamaan 2

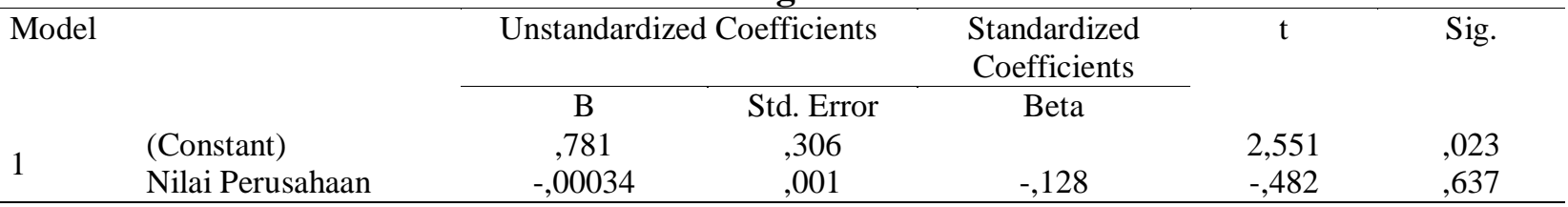

Dari tabel tersebut menghasilkan persamaan model 2 sebagai berikut:

$\mid$ residual $\mid=0,781+(-0,00034)$ Nilai perusahaan

Berdasarkan model persamaan regresi di atas menunjukkan bahwa semakin rendah nilai residual struktur modal, profitabilitas, pertumbuhan perusahaan, dan free cash flow akan berdampak pada nilai perusahaan turun, dikarenakan nilai koefisien regresi dari nilai perusahaan sebesar 0,00034 bersifat negatif dan menunjukkan tidak adanya hubungan yang searah dengan nilai perusahaan dengan residual (penyimpangan).

\section{Pengujian Hipotesis Empat}

Uji t untuk hipotesis yang keempat adalah untuk menguji koefisien regresi secara parsial pada variabel nilai perusahaan dengan nilai residual (penyimpangan) yang dihasilkan antara struktur modal, profitabilitas, pertumbuhan perusahaan, dengan free cash flow.

Dari Tabel 8 diatas memperlihatkan hasil bahwa tingkat signifikansi yang dihasilkan variabel nilai perusahaan sebesar $0,637>\alpha=0,05$ (level of signifikan), dan menyatakan pengaruh nilai perusahaan yang diproksikan melalui variabel PBV terhadap nilai residual adalah positif dan tidak signifikan.

\section{PEMBAHASAN HASIL PENELITIAN}

\section{Pengaruh Struktur Modal terhadap Nilai Perusahaan}

Hasil dari pengujian variabel struktur modal yang diproksi melalui debt to equity rasio mempunyai pengaruh negatif dan tidak singifikan terhadap nilai perusahaan, sehingga hipotesis pertama tidak bisa diterima. Keadaan ini membuktikan bahwa semakin menurun tingkat DER maka nilai perusahaan akan tinggi dan sebaliknya jika nilai suatu DER menurun maka nilai perusahaan akan rendah. Kebijakan mengenai struktur modal dikaitkan dengan penggunaan hutang dalam operasional perusahaan, karena semakin kecil hutang akan meningkatkan nilai perusahaan. Tetapi pemakaian lebih banyak utang akan memperbesar tingkat pengembalian yang diharapkan ini diakibatkan adanya pemakaian modal yang melibatkan lebih banyak utang akan memperbesar dampak yang akan ditanggung oleh pemegang saham, namun disisi lain akan meningkatkan pengembalian yang diharapkan (expected rate of return) yang berdampak pada menaiknya harga saham, sehingga struktur 
modal yang maksimal wajib menggapai sesuatu penyeimbang antara efek serta pengembalian yang mengoptimalkan harga saham (Modigliani \& Miller, 1961).

\section{Pengaruh Profitabilitas terhadap Nilai Perusahaan}

Hasil hipotesis kedua yang diajukan ditolak dalam pengujian variabel profitabilitas yang diproksi dengan return on equity dikarenakan menunjukkan pengaruh positif dan tidak signifikan terhadap terhadap nilai perushaan. Alasan ini adanya kondisi memperlihatkan semakin baik posisi perusahaan dan semakin besar kemampuan perusahaan untuk menyimpan investasi yang digunakan maka tinggi nilai return on equity. Rasio return on equity mengiidentifikasikan dalam penilaian informasi investor dalam nilai perusahaan dan bisa memulai berinvestasi.

Ketidak signifikan ini dimungkinkan pihak eksternal tidak tertarik pada keahlian industri dalam menciptakan laba. Tetapi memandang prospek industri di masa depan, pihak investor lebih memperhitungkan aspek eksternal spesialnya issue tentang kebijakan pemerintah Indonesia berkaitan dengan keinginannya buat mempunyai sebagian saham Freeport.

\section{Pengaruh Pertumbuhan Perusahaan terhadap Nilai Perusahaan}

Hasil pengujian pertumbuhan perusahaan menghasilkan pengaruh positif dan signifikan terhadap terhadap nilai perusahaan, sehingga hipotesis ketiga yang diajukan diterima. Hasil ini menunjukkan perusahaan yang mengalami pertumbuhan pesat akan membutuhkan modal yang cukup besar dalam hal membiayai pertumbuhan perusahaan, sehingga apabila suatu laba perusahaan yang ditahan banyak maka akan meningkatnya nilai suatu dividen payout ratio dan Informasi tersebut sangat direspon positif oleh para investor. Dari sudut pandang penilaian investor, jika terjadi peningkatan pertumbuhan suatu perushaan maka akan menunjukkan perusahaan tersebut memiliki aspek yang menguntungkan dan dampaknya para investor akan tertarik untuk melakukan investasi sehingga akan meningkatkan harga saham dan nilai industri.

Pengaruh Free Cash Flow terhadap hubungan antara Struktur Modal, Profitabilitas,

\section{Pertumbuhan Perusahaan dan Nilai Perusahaan.}

Masuknya free cash flow tidak mampu secara signifikan memoderasi pengaruh struktur modal, profitabilitas dan pertumbuhan perusahaan terhadap nilai perusahaan. Hasil ini menunjukkan hipotesis keempat yang diajukan tidak dapat diterima. Meskipun arus kas bebas perusahaan besar namun perusahaan membagikan deviden yang stabil sehingga pemegang saham tidak mempermasalahkan alokasi arus kas bebas atau tidak menuntut manajemen membagikan arus kas bebas sebagai tambahan deviden. Perusahaan yang 
memiliki "free cash flow dalam jumlah yang memadai akan lebih baik dibagikan pada pemegang saham dalam bentuk dividen untuk menghindari agency problem, hal ini dimaksudkan agar free cash flow yang ada tidak digunakan untuk sesuatu atau proyek-proyek yang tidak menguntungkan (wasted on unprofitable) dengan demikian ketersediaan dana dapat dipakai untuk pemegang saham" (Mollah et al, 2000 dalam Maqsudi dan Ambon, 2004).

\section{KESIMPULAN}

Kesimpulan hasil penelitian ini dapat dikemukakan sebagai berikut: (1). Struktur modal berpengaruh negatif dan tidak singifikan terhadap nilai; (2). Profitabilitas berpengaruh negatif dan tidak signifikan terhadap terhadap nilai perusahaan; (3). Pertumbuhan perusahaan berpengaruh positif dan signifikan terhadap nilai perusahaan; (4). Free cash flow tidak mampu secara signifikan memoderasi pengaruh struktur modal, profitabilitas dan pertumbuhan perusahaan terhadap nilai perusahaan. Saran untuk penelitian mendatang agar dapat menambahkan variabel yang tidak ada dalam penelitian dan dengan objek penelitian yang berbeda.

\section{REFERENSI}

Brigham, E. F., \& Houston, J. F. (2010). Manajemen Keuangan Edisi Kedelapan. In Erlangga Jakarta. https://doi.org/10.1016/0377-841X(78)90069-4

Brigham, E. F., \& Houston, J. F. (2013). Dasar-Dasar Manajemen Keuangan. In Salemba Empat. https://doi.org/10.1145/2505515.2507827

Dewi Teresia, E. S., \& Hermi, H. (2016). Pengaruh Struktur Kepemilikan, Ukuran Perusahaan dan Keputusan Keuangan terhadap Nilai Perusahaan dengan Pertumbuhan Perusahaan sebagai Variabel Moderating. Jurnal Magister Akuntansi Trisakti. https://doi.org/10.25105/jmat.v3i1.4969

Eugene F. Brigham and Joel F. Houston. (2015). Fundamentals of Financial Management. In Cengage Learning. https://doi.org/10.1017/CBO9780511790546.026

Freeport, P. (n.d.). freeport indonesia. Retrieved from PT. Freeport Indonesia website: https://ptfi.co.id/id/about

Ghozali, I. (2009). Aplikasi Multivariate dengan Program SPSS edisi III. Semarang: Badan Penerbit UNDIP. https://doi.org/10.1016/j.oooo.2017.11.003

Ghozali, I. (2013). Aplikasi Analisis Multivariate Dengan Program IBM dan SPSS 21. In Aplikasi Analisis Multivariate dengan Pogram iIBM SPSS 21. https://doi.org/10.1126/science.1158668

Jemani, K. R., \& Erawati, T. (2020). Pengaruh Profitabilitas terhadap Nilai Perusahaan dengan Struktur Modal sebagai Variabel Intervening pada Perusahaan Manufaktur yang Terdaftar Di Bei. Kajian Bisnis STIE Widya Wiwaha, 28(1), 51-70. https://doi.org/10.32477/jkb.v28i1.377

Keown, A., Martin, J., \& Petty, W. (2014). Foundations of Finance - The logic and Practice of Financial Management 8e. In Pearson. https://doi.org/10.2307/2326337

Kumala dewi, D., R. tanjung, A., \& Indrawati, N. (2018). Analisis Pengaruh Free Cash Flow, 
Investment Opportunity Set, Ukuran Perusahaan dan Kepemilikan Manajerial terhadap Nilai Perusahaan dengan Kebijakan Hutang sebagai Variabel Moderating. Jurnal Ekonomi, 26(2). https://doi.org/10.1017/CBO9781107415324.004

Kusumaningtyas, F., Dewi, R. R., \& Chomsatu, Y. (2018). Pengaruh Rasio Keuangan dan Pertumbuhan Perusahaan terhadap Kebijakan Dividen. Jurnal Ekonomi, 6.

Modigliani, F., \& Miller, M. (1961). Dividend Policy, Growth, and The Valuation of Shares. The Journal of Business.

Mukhlasin. (2002). Analisis Pemilihan Metode Akuntansi Persediaan dan Pengaruhnya terhadap Earning Price Ratio. Simposium Nasional Akuntansi 5.

Notoatmodjo. (2017). Notoatmodjo, S. 2010. Metodologi Penelitian Kesehatan. Jakarta: Rineka Cipta. Journal of Chemical Information and Modeling. https://doi.org/10.1017/CBO9781107415324.004

Pratama, I. S. (2018). Pengaruh Struktur Modal dan Likuiditas terhadap Nilai Perusahaan dengan Profitabilitas sebagai Variabel Intervening. Prosiding 2nd Business and Economics Conference In Utilizing of Modern Technology.

Putra, I. A. M. C. D. I. W. (2017). Free Cash Flow Sebagai Pemoderasi Pengaruh Earnings Manajement dan Kebijakan Deviden pada Nilai Perusahaan. 18, 1259-1285.

Ramadhani, Y. C., \& Maryam, D. (2018). Pengaruh Struktur Modal, Profitabilitas, Likuiditas dan Nilai Pasar terhadap Nilai Perusahaan dengan Dividend sebagai Variabel Moderasi. Seminar Nasional Dan Call for Paper, 1(1), 904-923. https://doi.org/10.31843/jmbi.v5i2.163

Sartono, R. A., \& Sri Asih, A. M. (2013). An Empirical Examination of The Dividend Information Contents in The Balance Sheet: A Signaling Approach*. Gadjah Mada International Journal of Business. https://doi.org/10.22146/gamaijb.5387

Sri, H. (2013). Pengaruh Profitabilitas, Growth Opportunity, Sruktur Modal terhadap Nilai Perusahaan pada perusahaan Publik di Indonesia. Jurnal Buletin Ekonomi Moneter Dan Perbankan, 1, 127-148.

Suastini, N. M., Ida, B. A. P., \& Henny, R. (2016). Pertumbuhan Perusahaan terhadap Nilai Perusahaan pada Perusahaan Manufaktur di Bursa Eefek Indonesia (Struktur Modal sebagai Variabel Moderasi) Fakultas Ekonomi dan Bisnis Universitas Udayana (Unud), Bali, Indonesia Nilai Perusahaan Menggambarkan Kem. Jurnal Ekonomi Dan Bisnis Universitas Udayana, 5(1), 143-172.

Sugiono. (2014). Metode Penelitian Pendidikan Pendekatan Kuantitatif.pdf. In Metode Penelitian Pendidikan Pendekatan Kuantitatif, Kualitatif Dan R\&D.

Suharli, M. (2007). Pengaruh Profitability dan Investment Opportunity Set terhadap Kebijakan Dividen Tunai dengan Likuiditas sebagai Variabel Penguat. Jurnal Akuntansi \& Keuangan. https://doi.org/10.1016/j.jce.2013.07.003

Susantika, B., \& Mahfud, M. K. (2019). Profitabilitas sebagai Variabel Intervening (Studi pada Perusahaan Manufaktur Sektor Aneka Industri yang Terdaftar di Bursa Efek Indonesia Tahun 2012-2016 ). Journal of Management, 8(1), 137-150.

Wahyuni, W., Suratno, \& Anwar, C. (2017). Pengaruh Intellectual Capital terhadap Nilai Perusahaan dengan Free Cash Flow sebagai Variabel Moderating. Jurnal Ilmiah Ilmu Ekonomi. 